\title{
Isolation and Characterization of a Bacteriophage Infecting Pseudomonas Aeruginosa and Its Application as a Potential Decontaminating Agent
}

\author{
Sonika Sharma ( $\nabla$ ssharma@drl.drdo.in ) \\ Defence Research Laboratory \\ Sibnarayan Datta \\ Defence Research Laboratory \\ Soumya Chatterjee \\ Defence Research Laboratory \\ Moumita Dutta \\ National Institute of Cholera and Enteric Diseases \\ Jhuma Samanta \\ Defence Research Laboratory \\ Mohan G Vairale \\ Defence Research Laboratory \\ Rajeev Gupta \\ Defence Research Laboratory \\ Vijay Veer \\ Defence Research Laboratory \\ Sanjai K Dwivedi \\ Defence Research Laboratory
}

Research Article

Keywords: Bacteriophage, Biocontrol, Wastewater, Multidrug resistance, Pseudomonas aeruginosa

Posted Date: May 27th, 2021

DOI: https://doi.org/10.21203/rs.3.rs-536850/v1

License: @ (1) This work is licensed under a Creative Commons Attribution 4.0 International License. Read Full License 


\section{Abstract}

To treat antibiotic resistance bacteria, bacteriophage (also called 'phage') application has recently drawn considerable attention from researchers globally. Bacteria like Pseudomonas aeruginosa are known to be associated with nosocomial infections especially in patients with compromised immune systems. In the present work, phage against P. aeruginosa (named 'DRLP1') was isolated from wastewater, enriched and characterized. Morphologically DRLP1 belongs to the family Myoviridae with a high lytic ability. DRLP1 has a burst size of approximately 100 PFU/infected cells, a rapid adsorption time when supplemented with $\mathrm{MgCl}$, and has viability in a wide temperature range and $\mathrm{pH}$. Genomic sequencing and bioinformatics analysis showed that the phage genome is linear double-stranded, 66,243 bp in length and have a GC content of $54.9 \%$. the genome encodes 93 phage related ORFs open reading frames (ORFs). Phage stability in lyophilized state, adsorption study on sodium alginate beads, and in-vitro pathogen reduction assays were also investigated. Study carried out with artificially contaminated fomites suggests that this phage has the potential for application as a biological decontaminant agent against $\mathrm{P}$. aeruginosa in different conditions.

\section{Introduction}

For several decades antibiotics have been playing an important role as therapeutics and prophylactic in various fields like clinical usage, healthcare, veterinary, and agriculture industries, etc. However, in discriminate of antibiotics has resulted in the advent of multi drug resistant (MDR) bacteria and the low efficacy of common antibiotics in treating these MDR bacteria. As predicted by Bassetti et al. ${ }^{1}$ by 2050 , antibiotic resistance will result in 10 million deaths per year. Moreover, patients with chronic illnesses are more likely to develop antibiotic resistance infections, therefore; the treatment risk associated with immunecompromised individuals is much higher than the normal patient.

Pseudomonas aeruginosa is one of the most common pathogens which are known to acquire resistance against antibiotics. It can also adapt to different environmental conditions and is prevalent in sources like hospitals, animal farms, slaughterhouses, soil, aquatic environments, and sewage water ${ }^{2,3}$. Further, $P$. aeruginosa is associated with nosocomial infection and causes several health issues, including cystic fibrosis, urinary tract infections, dermatitis, soft tissue infections, complications in patients with severe burns and open wounds ${ }^{4}$. Also, the presence of flagella and type IV pili, allows $P$. aeruginosa motility on solid or semi-solid surfaces, resulting in contamination of surfaces and tools, especially in clinical settings ${ }^{5,6}$. The re-emergence of phage therapy to target specific bacteria especially multidrug resistance bacteria has brought a paradigm shift in the development of a new class of antibacterial. Harnessing lytic activity of phages against specific bacteria is a targeted and effective approach, however; certain limitations lie with it also. Moreover, using phage to treat bacteria is harmless to humans and the environment too. Bacteriophages (or phages) are abundant (ubiquitous) in every part of our ecosystem ${ }^{7}$. A huge volume of data has shown that the human gut harbor an extensive diversity of phages that modulates bacteriome inside the gut either by direct infection or by regulating the human immune system ${ }^{8}$, and sewage water receiving fecal matters provides a suitable medium for the growth of diverse gut bacteriophages and hence considered as a reservoir of phages against various pathogenic bacteria. Recently, researchers have successfully demonstrated the potential application of phage therapy in treating certain superbug infections that were otherwise untreatable using conventional approaches.

To date, there are only a few reports from India on detailed characterization of bacteriophage isolated from wastewater and most of the phages are uncharacterized. In the present work, a phage against $P$. aeruginosa was isolated from wastewater, enriched and characterized. In this manuscript, we report the results of this study and demonstrate it application as a decontaminating agent.

\section{Results}

\section{Morphological of DRL-P1}

Isolated phage was screened against $P$. aeruginosa through spot test. A clear zone over the bacteria lawn was observed due to the lytic activity of phage (Fig. 1a). This lytic phage was named 'DRLP1'which was further identified and characterized. Further, 'DRLP1' produced clear small plaques of 2 mm in diameter of similar morphology indicating lytic activity against $P$. aeruginosa (Fig. 1b). Further, bacteriophage enrichment was performed by repeated plaque purification method and a stock of $10^{9} \mathrm{PFU} / \mathrm{ml}$ was prepared for further studies and characterization (Fig. 1c). Purified phages were examined under transmission electron microscopy (TEM) and classified according to the guidelines of the International Committee on Taxonomy of Viruses (ICTV). TEM images revealed the presence of phage belonging to the Family Myoviridae under the Order Caudovirales, signified by a neck, contractile tail, base plate, and the tail fibers (Fig 2. a, b, c, \& d). DRLP1 had a capsid of $70 \mathrm{~nm}$ diameter and a contractile tail that was about $120 \mathrm{~nm}$ long and $20 \mathrm{~nm}$ in diameter.

\section{Antibiotic sensitivity and host range}

The antibiotic resistance pattern of the isolate is shown in Table (Supplementary data, Table.S1).Resistance was documented against Ceftazidime (CAZ), Nitrofurantoin (NIT), Nalidixic acid (NA), Ampicillin (AMP),Co-Trimoxazole (COT). However, $P$. aeruginosa isolates were found sensitive to certain antibiotics including Ciprofloxacin (CIP), Amikacin (AK), Amoxyclav (AMC), Cefotaxime (CTX), and Gentamicin (GEN), while intermediate sensitivity was documented against Netillin (NET), Tobramycin (TOB). Moreover, bacteriophages are highly specific, with the majority of them infecting only a single species of bacteria. DRL-P1 did not show lytic activity against other bacteria, including Escherichia coli(443), Vibrio cholera [Classical 01] (3904), Bacillus megaterium (428), Shigella flexneri (1457), P. aeruginosa (1688), Bacillus subtilis (1305), Salmonella typhimurium (1252), Salmonella typhimurium (1251), Streptococcus pyrogenes (442), Klebsiella pneumonia (8911) however, the clear lytic zone was observed on pseudomonas isolates (IS1-IS9) isolated from soil samples of Arunachal Pradesh, India. Their characterization is being done in the laboratory (Supplementary data, Table.S2).

\section{Features of the DRLP1 genome}


NGS-based sequencing resulted in the generation of a total of 1,295,948 raw reads (read length 150) amounting to $194.4 \mathrm{Mb}$ bases. After sequence QC, a total of $1,221,536$ reads ( $178.93 \mathrm{Mb}$ bases) were used to assemble a terminally redundant genome of 66,243 nts having GC content of $54.9 \%$, consisting of $22.75 \%$ A, $22.31 \%$ T, $27.52 \%$ G, and $27.40 \%$ C. The genome sequence was predicted to be 'intact' (completeness score 120) in PHASTER analysis. In Blastn search, the DRL-P1 phage genome sequence was found to be most similar to Pseudomonas phage sequences from the genus Pbunavirus (Order: Caudovirales; Family: Myoviridae), with top 10 hits namely being isolates- DL52 (KR054028), misfit (MT119367), zikora (MW557846), R26 (NC_048663), datas (NC_050143), Epa 14 (NC_050144), billy (MT133563), elmo(MT119364), kraken (KT372692), Jollyroger (KT372691), showing percent nucleotide identity (PNI) ranging from $95.55 \%-97.77 \%$ over $99 \%$ query coverage.

A total of 93 phage-hit ORFs were identified, of which 36 were functionally annotated based on homology with similar phage proteins, while 57 were annotated as phage hypothetical proteins. Predicted ORFs were found to encode proteins ranging from 31-1035 aa in length, the largest being the DNA polymerase ORF (Table 1). Identified ORFs included genetic regions, responsible for encoding proteins related to virion structure, genome replication, assembly \& packaging, DNA synthesis \& repair, regulation of gene expression, host identification \& infection, host lysis, and recombination that are essential for the phage cycle. Among the 93 ORFs, 54 (58\%) and 39 (42\%) ORFs were encoded on each of the strands of the dsDNA, respectively. The strand with most of the ORFs was considered as the plus strand in further analyses. A genome map showing predicted ORFs (with definite phage-related proteins) is presented in (Fig. 3). Together, all the ORFs were encoded within 65,495 bps (from nts 634 to 66,128 nt), resulting in an extremely high coding density of $98.87 \%$. Notably, the start codon of 25 ORFs (26.88\%) overlapped with the stop codon of the previous gene, suggesting transcriptional interactions among these neighboring genes. No putative tRNA encoding genes were identified in the genome. A total of 83 promoter regions and 27 Rho-independent terminators across the genome sequence were identified (Supplementary data, Table. S3 \& S4 ). No antimicrobial resistance-related gene was predicted in the genome.

Subsequently, phylogenetic trees were reconstructed for Terminase and DNA polymerase III genetic sequences with top 100 BLAST hit sequences (including RefSeq sequences). In the Terminase phylogeny (Fig. 4), DRL-P1 clustered with a Pbunavirus RefSeq (NC_028745, isolate 'DL60' from the UK) and an unclassified Pbunavirus (MW557846, isolate 'zikora', recently isolated from Nigeria). In the DNA polymerase III generated phylogeny (Fig. 5), DRL-P1 clustered with two unclassified Pbunaviruses (MW557846, isolate 'zikora' and MT119364, isolate 'elmo'). However, the DNA polymerase sequence of DRL-P1 was phylogenetically closer to RefSeq NC_050143 (isolate 'datas') and another isolate 'DL52' (KR054028), diverging from the phylogenetic relatedness of the Terminase genetic region with RefSeq NC_028745 (isolate 'DL60'). Therefore, a phylogeny was constructed with whole-genome sequences to resolve this conflict. In the complete genome phylogeny (Fig. 6), DRL-P1 showed the closest phylogenetic relatedness with 'zikora', and relationship with isolate 'datas', corroborating with the DNA polymerase genetic region phylogeny.

The relationship of the DRL-P1 became further complicated in the results of VIRIDIC analyses. When the analysis was performed only with 37 genus Pbunavirus RefSeq genomes, DRL-P1 was included in the species cluster 1 along with RefSeq NC_011810 (isolate 'PB1') with a PNI score of 95.34\% (Supplementary data, Table S5). However, when analyzed against 100 top BLAST hits including 37 RefSeq and 63 other complete genome sequences, DRL-P1 was placed in a cluster (separately from isolate 'PB1') along with isolates DL52, zikora, elmo, and steven (MT119370), having PNI ranging from 96.0 to 97.5\% \% (Supplementary data, Table S6 \& Table S7). In the VIRIDIC analysis of complete genomes, PNI of DRL-P1 was calculated to be 93.3 and 92.8 with isolates DL60 and datas, respectively, which were found to be most closely related in previous phylogenetic analysis of the Terminase and DNA Polymerase III genetic regions.

Results from the phylogenetic analyses and the VIRIDIC analysis suggested a possibility of horizontal gene transfer or recombination, which is better represented in NeighborNet (NN), as compared to phylogenetic trees. Therefore, a NN was reconstructed with RefSeq and DRL-P1 complete genome sequence (Fig. 7). Extensive reticulation at the base of the NN suggested frequent exchanges of sequences among the ancestral isolates in the evolution and emergence of present isolates. The NN represented the relation of DRL-P1 with various other isolates including datas (closest isolate), PB1, DL60, AB28 (NC_026600), supporting the divergence observed in clustering in the terminase and the DNA polymerase phylogenies. Subsequent analysis of recombination using RDP4 program detected with a high probability value, evidence of large fragment of sequences similar to the isolates datas, PB1, while smaller fragments of sequences from other isolates (Fig. 8 \& Table-2). This suggested that the evolution of the DRL-P1 genome involves frequent genetic interaction with different Pbuna viruses.

\section{Phage adsorption and growth kinetics}

\section{Effect of Calcium and magnesium ion on Adsorption rate:}

Within 5 min approximately $90 \%$ of phages were adsorbed in the samples supplemented with $\mathrm{MgCl}_{2}$ and after 15 mins only $4 \%$ phages remained unabsorbed. Only $1 \%$ percent of the phages were in free form whereas maximum adsorption was observed at around 20 min without adding $\mathrm{MgCl}_{2}$. The study indicates that $\mathrm{Mg}^{2+}$ ions accelerate the phage adsorption by increasing phage infectivity hence resulting ineffective lysis of the host bacterium (Fig $9 . \mathrm{a}$ )

\section{Single-step growth curve}

A single-step growth curve was calculated for $P$. aeruginosa phage as shown in (Fig. 9b) The latent period was determined to be about 30 min which signifies the time interval between phage adsorption and the start of the first burst. The duration of the rise period was $40-50$ min with a burst size of 100 PFU/infected cells during the experiment.

\section{Stability of phage at different temperatures and $\mathrm{pH}$ condition}

The temperature vs. phage stability was observed at six different temperatures viz. $4^{\circ} \mathrm{C}, 25^{\circ} \mathrm{C}, 37^{\circ} \mathrm{C}, 40^{\circ} \mathrm{C}, 50^{\circ} \mathrm{C}, 60^{\circ} \mathrm{C}$, and $70^{\circ} \mathrm{C}$. Results demonstrated that the purified $P$. aeruginosa phage was considerably stable at $4^{\circ} \mathrm{C}, 25^{\circ} \mathrm{C}, 37^{\circ} \mathrm{C}$. Further, phage stability was also noted at $40^{\circ} \mathrm{C}$. However, at temperatures above 
$40^{\circ} \mathrm{C}$, stability was found to decrease significantly (Fig. 10 a). A decrease in phage titer was noted at 50 and $60^{\circ} \mathrm{C}$. Further, at $70^{\circ} \mathrm{C}$ only $14 \%$ phage survivability was documented.

After $18 \mathrm{~h}$, the phage was stable at $\mathrm{pH} 6,7$, and 8 without any significant loss in the titer. However, beyond pH 10 and below pH 3 very little phage percentage was recorded. Approx. 70\% phages were viable between pH 5 and 10. Also, no plaque formation was seen at pH 1, 2, 13, and 14. (Fig.10 b)

\section{Decontamination of fomites through phage preparations}

In the present work, we used glass coverslip and surgical blade to represent solid surface and surgical tool, respectively to demonstrate decontamination by application of phages. The ability of phages to decontaminate $P$. aeruginosa infection was determined according to Jensen et al. ${ }^{9}$. Reduction in the bacterial count was recorded to be 1.2 logs in glass coverslip and 1 log in surgical blade decontamination, respectively (Fig. 11a \& 11b).

\section{Phage action on bacteria:}

Phage action on bacteria was observed through a change in OD at $600 \mathrm{~nm}$. Bacterial control (MOI:0) showing a sigmoid curve representing a continuous increase in optical density (OD) 600 values during the $8 \mathrm{~h}$ of incubation whereas, bacteria mixed with phages at different MOI: 1, 0.1, 0.01 , and 0.001 , indicates the reduction of bacteria with phage application (Fig.12). At different $\mathrm{MOI}$ bacterial growth increased up to 60 min then lysed by phage at an $\mathrm{MOI}$ of 1 to 0.001 .

\section{Stability of lyophilized phage and after encapsulation on alginate:}

Lyophilization of bacteriophage stock $\left(10^{9} \mathrm{PFU} / \mathrm{ml}\right)$ in both skim milk and sucrose resulted in a slight drop in the phage titer (10 $\left.0^{8} \mathrm{PFU} / \mathrm{ml}\right)$. Once lyophilized, even after 12 months, the lyophilized sample retains its lytic activity without a further drop in the titer. Samples were reconstituted in 2 ml TM buffer and plaque assay was performed for PFU count. Similarly, phage was adsorbed over sodium alginate beads (5-6 mm), the lytic activity of encapsulated and nonencapsulated bacteriophage was tested against $P$. aeruginosa by placing a bead over the lawn of $P$. aeruginosa. The clear zone was reported with the adsorbed phage over the bead.

\section{Discussion}

The work presented here aims at isolation and characterizing lytic phage against $P$. aeruginosa. Through genome sequencing, TEM, and growth-related parameters detailed characterization was performed. Further, experiments were carried out to evaluate the lytic potential of the isolated phage as a decontaminant agent. Bacteriophage isolated from wastewater has shown its efficiency in plaques formation, which may be due to the lysis function of endolysin. There have been several reports on the isolation of phages against $P$. aeruginosa from sewage water ${ }^{10-14}$. However, limited reports are available on their genomic characterization, especially from India. According to studies, $P$. aeruginosa is a potent pathogen for humans and can easily acquire resistance against antibiotics, in recent times ${ }^{3,15}$. The isolated $P$. aeruginosa is resistant to a range of antibiotics, including synthetic derivatives of the drug like nalidixic acid and nitrofurantoin. Resistance was also reported against cotrimoxazole which is a combination drug and has been found effective in treating infections involving multiple systems of the body, hence, called miracle drug ${ }^{16}$. More interestingly, in cases of antibiotics resistance, biofilm acts as a physical barrier and considered as an important strategy for bacterial survival and such strategies have been reported in cases of human infection with $P$. aeruginosa ${ }^{17,18}$ consequently, the efficacy of antibiotic gets decreased. Nevertheless, phage application to remove biofilms has been reviewed recently ${ }^{19,20}$. In the current scenario of infection with critical pathogens, phage therapy has been suggested to be an exciting alternative, especially against multidrug resistance bacteria $^{8,21,22}$.

To further characterize the phage, we have studied its multiple growth parameters through a single step growth curve which helps in defining phage lytic potential for biocontrol of bacteria ${ }^{23,24}$. Results indicated a latent period of $30 \mathrm{~min}$ followed by a burst size of 100 phages/cell. In addition, the stability of the phages at various temperatures and $\mathrm{pH}$ remains critical in clinical and/environmental settings as well as in biological applications. The data show DRLP1 phage has high stability in a wide range of temperatures and $\mathrm{pH}$ conditions. The study also supports the potential application of our preparation for field usages. Moreover, phage stability at a wide $\mathrm{pH}$ range indicates that wastewater phages can tolerate temperature and $\mathrm{pH}$ fluctuations and can withstand different environmental conditions.

Further, our results from decontamination assays showed significant efficiency of phages in reducing bacterial load on solid surfaces. Solid surface and small surgical tools can be effectively decontaminated by phage treatment. Similar surface decontamination by phage application has been shown by Jensen et al.

${ }^{9}$ and Rashid et al. ${ }^{25}$. In addition, there is always a risk associated with MDR P. aeruginosa of nosocomial transmission especially in immunocompromised patients, and formation of biofilm, swarming motility, quorum sensing, multiple processes for adaptation, etc. in $P$. aeruginosa make it a more potent carrier for nosocomial transmission. It has been observed that urinary catheterization; nasogastric feeding can also spread nosocomial infections ${ }^{26}$. Available works of literature have demonstrated the efficacy of phages especially for the control of $P$. aeruginosa ${ }^{27,28}$. Likewise; a study carried out by Fu et al. ${ }^{29}$ demonstrated the phage application in treating biofilm formation by $P$. aeruginosa in an in vitro model. Further, application of phage at low $\mathrm{MOI}$ of 0.01 and 0.001 resulted in decreased bacterial load which indicates our phage as a promising antimicrobial agent against $P$. aeruginosa.

The immense potential of phage therapy in treating fatal superbugs infections has recently drawn the attention of phage biologists and to hasten its availability and timely matching, phage preservation is in the lytic phase is necessary. Researchers are trying to improve phage stability under different storage conditions. For example, Manohar \& Ramesh ${ }^{30}$ reported that lyophilization in presence of suitable excipients like (sucrose, gelatin, and sucrose plus gelatin) helps in retaining phage viability during long-term storage. In our experiments titer slightly drop from ( $\left.10^{9} \mathrm{PFU} / \mathrm{ml}\right)$ to $10^{8} \mathrm{PFU} / \mathrm{ml}$ on lyophilization. Similarly, 
other reports have also shown a decrease in phage titer on lyophilization ${ }^{30-32}$. We also encapsulate phage within the alginate beads and have seen its lytic activity over $P$. aeruginosa lawn. Earlier, Moghtader et al. ${ }^{33}$ studied the stability and sustained released of T4 phages encapsulated with alginate beads coated with chitosan, polyethylene imine (PEI). Phage in the encapsulated form will provide stability to phage in non-refrigerated condition and can be transported without compromising much with its titer ${ }^{30}$.

\section{Materials \& Methods}

\section{Phage isolation, purification, and preparation}

Collection of wastewater sample was done from a community waste treatment facility (receiving human fecal matter), from Tezpur, Assam ( $26^{\circ} 39^{\prime} 4.3848^{\prime \prime} \mathrm{N}$ and $92^{\circ} 47^{\prime} 1.7268^{\prime \prime} \mathrm{E}$ ). The host bacteria ( $P$. aeruginosa) were isolated and grown on cetrimide agar (Himedia, Mumbai, India). The wastewater sample was spin down at $12,000 \mathrm{~g}$ for $10 \mathrm{~min}$ to remove debris and coarse matter, followed by serially passing through membrane filters of $0.45-\mu \mathrm{m}$ and $0.22-\mu \mathrm{m}$-pore-size (whatman). P. aeruginosa culture in the early exponential phase (approximately $10^{7} \mathrm{CFU} / \mathrm{ml}$ ) were infected with the filtrate obtained and allowed to infect the host cells at $37^{\circ} \mathrm{C}$ overnight with mild shaking $(180 \mathrm{rpm})$. The presence of lytic phages in the sample was identified through spot tests. A single plaque was picked and suspended in TM buffer $(8.5 \mathrm{mM} \mathrm{MgCl} 2,50 \mathrm{mM}$ Tris- $\mathrm{HCl}, \mathrm{pH} 7.8)$. Titre of the phage was checked by making dilution of released phage and infecting it with fresh log-phase $P$. aeruginosa culture. Subsequently, phage lysate of $10^{9} \mathrm{PFU} / \mathrm{ml}$ was prepared by enriching phage with bacteria followed by PEG precipitation $\left(8 \% \mathrm{PEG}_{8000} \mathrm{wt} / \mathrm{voland} 1 \mathrm{M} \mathrm{NaCl}\right)^{34}$. The purified phage lysate was stored at $4{ }^{\circ} \mathrm{C}$. The fresh phage stock was sent for viewing under TEM.

This work has been reviewed and approved by the DRL-IBSC (approval DRL/IBSC/PROJ/10). All the microbiological experiments were carried out inside Biosafety level 2 (BSL2) cabinet (Esco, Singapore).

\section{Transmission Electron Microscopy (TEM)}

For TEM, purified phage particles $\left(10^{9} \mathrm{PFU} / \mathrm{ml}\right)$ were immobilized on Formvar carbon-coated copper grids (Nissin EM Corporation) and the grids were observed under TEM (TECNAI 200 KV TEM Fei, Electron Optics).

\section{Antibiotic sensitivity assay and host range}

Antibiotic sensitivity of the isolated P.aeruginosa strain was assessed using commercially available antibiotics coated Hexa discs G- minus 1 \&G- minus 2 (HiMedia, Mumbai, India). Results were interpreted following the Clinical Laboratory Standard Institute (CLSI) guidelines as resistant, intermediate, or

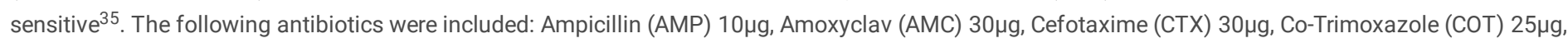

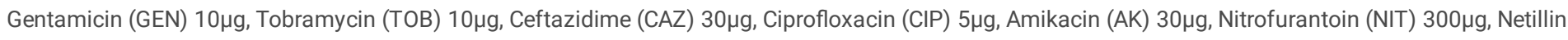
(NET) $30 \mu \mathrm{g}$, Nalidixic acid (NA) $30 \mu \mathrm{g}$.

The host range of DRLP1 was determined using a spot assay and confirmed using the double-layer agar technique. $5 \mu$ l of phage lysate (>10 $\left.{ }^{9} \mathrm{PFU} / \mathrm{mL}\right)$ was spotted over lawn of each bacterial strain mixed with top agar. After overnight incubation at $37^{\circ} \mathrm{C}$, the plates were examined for the presence of a lysis zone.

\section{Conventional phage study}

Adsorption assay was performed according to Kim et al. ${ }^{36}$ with little modification. To determine the adsorption rate with or without $\mathrm{MgCl}_{2}$, an exponentially growing host strain was infected with phage at an $\mathrm{MOI}$ of 0.1 and were poured into separate vials. In the first vial, $10 \mathrm{mmol} / \mathrm{L}$ of $\mathrm{MgCl}$, was added and the second vial was without $\mathrm{MgCl} 2$. At 0, 5, 10, 15, and 20 minutes post-infection, 100 $\mu \mathrm{L}$ aliquots of the sample were taken and diluted immediately in $900 \mu \mathrm{L}$ PBS, followed by centrifugation at $12,000 \mathrm{~g}$ for $5 \mathrm{~min}$. The titer of non-adsorbed free phages from both vials was determined by using the double-layer agar method.

A single-step growth curve was performed as per Kim et al. ${ }^{36}$. Briefly, $10 \mathrm{ml}$ exponentially growing $P$. aeruginosa culture was infected with phage particles at an $\mathrm{MOI}$ of 0.1 and were allowed to adsorb for $15 \mathrm{~min}$ at $37^{\circ} \mathrm{C}$. Subsequently, cells were pelleted by centrifugation ( $12,000 \mathrm{~g}$ for $\left.5 \mathrm{~min}\right)$ and un-adsorbed phages were removed by washing with fresh TSB. Cell pellets were resuspended in $10 \mathrm{ml}$ fresh TSB broth and incubated at $37^{\circ} \mathrm{C}$. Cultures were incubated for 120 mins and after every $10 \mathrm{~min}$; a sample was taken for phage titration. Each experiment was conducted in triplicate.

For thermal stability assays, equal volumes of TM buffer $(900 \mu \mathrm{l})$ were aliquoted in $1.5 \mathrm{ml}$ tubes. All the tubes were kept at their respective temperature for 30 min. Subsequently, $100 \mu$ l of phage dilution $\left(10^{7} \mathrm{PFU} / \mathrm{ml}\right)$ was added into preheated tubes and mixed gently and incubated at different temperatures $\left(4^{\circ} \mathrm{C}\right.$, $25^{\circ} \mathrm{C}, 37^{\circ} \mathrm{C}, 40^{\circ} \mathrm{C}, 50^{\circ} \mathrm{C}, 60^{\circ} \mathrm{C}, 70^{\circ} \mathrm{C}$, and $\left.80^{\circ} \mathrm{C}\right)$ for $60 \mathrm{~min}$. Phage stability at different $\mathrm{pH}[2,3,4,5,6,7,8,9]$ was also studied. Phage titer $\left(10^{7} \mathrm{PFU} / \mathrm{ml}\right)$ was added to each pH buffer and incubated for $18 \mathrm{hrs}$ at room temperature. In both the studies, plaque assay was performed and the percentage of surviving phage was calculated by final PFU count over initial PFU count ${ }^{37}$. Experiments were repeated in triplicates.

\section{Genome sequencing, annotation, and genome analysis}

For extraction of nucleic acids, phage particles released from the lysis of the host cells were collected by gently rinsing the top layer of 'web pattern plaque plates, using SM buffer. The high titer bacterial lysate was clarified by centrifugation at $14,000 \mathrm{~g}$ for 15 mins at $4^{\circ} \mathrm{C}$ and the clear supernatant was transferred to a fresh microcentrifuge tube. Subsequently, the supernatant was incubated with $50 \mathrm{U} \mathrm{mL}-1$ of DNase I (Sigma-Aldrich) and $40 \mathrm{U}$ mL-1 of RNase A (ThermoFisher Scientific) for $2 \mathrm{hrs}$ at $37^{\circ} \mathrm{C}$ to remove contaminating host nucleic acids, and DNase I was then inactivated by incubation at $80^{\circ} \mathrm{C}$ for 15 min. Capsid-protected phage DNA was released by proteinase K digestion for $2 \mathrm{hrs}$ at $56^{\circ} \mathrm{C}$, purified by repeated cycles of extraction in Phenol/ Chloroform/ Isoamyl alcohol, precipitated using isopropanol, and finally dissolved in TE buffer ${ }^{34}$. Quantity and quality of phage DNA preparation were evaluated spectro- 
photometrically (NanoPhotometer, Implen $\mathrm{GmbH}$, Germany). The integrity of DNA preparation was verified by electrophoresing an aliquot in $0.8 \%$ agarose gel, along with $\lambda$ DNA/Hind III marker.

Purified phage DNA was sent to a commercial facility for NGS-based whole genome sequencing (AgriGenome Labs Pvt. Ltd., Kochi, India). Following standard quality evaluation, a paired-end library was prepared (Next Ultra, New England Biolabs) and library quality was evaluated on an automated electrophoresis platform (Tape Station, Agilent), followed by sequencing on Illumina HiSeq NGS platform. After the sequencing run, adapter sequences were trimmed from the raw reads, reads with an average quality score of $<30$ in any of the paired-end reads were filtered out as well as unique reads were removed. High-quality paired-end reads were then assembled de novo, using the Iterative Virus Assembler ${ }^{38}$. Analysis of genome features of the resulting phage including ORF prediction and annotation were accomplished on GeneMarkS ${ }^{39}$ and PHASTER ${ }^{40}$ servers. Blastn (megablast) search was performed to find highly similar phage genome sequences in the NCBI GenBank ${ }^{41}$. BLASTX algorithm with E-value cutoff $\leq 10^{-3}$ was used to compare predicted genes with protein sequences submitted in the Uniprot database. A physical map of the annotated DRL-P1 phage genome was reconstructed using the SnapGene tool (trial version). The tRNAscan-SE program (http://lowelab.ucsc.edu/tRNAscan-SE/) was used to scan for potential tRNA genes in the genome ${ }^{42}$. Putative promoter regions were identified using the Neural Network Promoter Prediction program ${ }^{43}$ hosted on the Berkeley Drosophila Genome Project website (www.fruitfly.org/seqtools/promoter.html), with a minimum promoter score set at 0.9 . To identify Rho-independent transcription terminators, the ARNOLD server (http://rssf.i2bc.paris-saclay.fr/toolbox/arnold/index.php) was used ${ }^{44}$. The lifestyle of the phage was predicted using the PHACTS server (http://www.phantome.org/PHACTS/index.php) ${ }^{45}$. Antimicrobial resistance (AMR) genes and variants were predicted using the Resistance Gene Identifier (RGI) tool ${ }^{46}$ incorporated in the Comprehensive Antibiotic Resistance Database (CARD) server (https://card.mcmaster.ca/analyze/rgi).

For reconstruction of evolutionary history, complete genome sequences resulting from BLAST search and well-annotated reference sequences (RefSeq database ${ }^{47}$ ) were retrieved from the NCBI Virus database (https://www.ncbi.nlm.nih.gov/labs/virus/vssi/\#/). Genomic or subgenomic sequences (DNA polymerase/ Terminase encoding genetic regions) were manipulated using BioEdit ${ }^{48}$. Multiple sequence alignments were done using the MAFFT online server $^{49}$, allowing adjustment of sequence orientation, during alignment. The neighbor-Joining method was employed to infer evolutionary history. The maximum Composite Likelihood algorithm was used to calculate evolutionary distances and bootstrap tests (1000 replicates) were performed to examine the reliability of clustering among the taxa. Ambiguous positions were excluded during analyses. All the molecular evolutionary analyses were performed using the MEGAX program ${ }^{50}$.

Pairwise intergenomic similarities among the related phage genomes were calculated using the Virus Intergenomic Distance Calculator (VIRIDIC) ${ }^{51}$, which is based on the algorithm used by the ICTV (International Committee on Taxonomy of Viruses) to compute intergenomic similarities among Bacterial and Archaeal Viruses. Easyfig software ${ }^{52}$ was used for the construction of multiple amino acid sequence alignments.

\section{Sequence Accession Numbers}

The genome sequence of DRLP1 was submitted in NCBI GenBank and is available under accession number MN564818.

\section{Fomites Decontamination Assay}

For a demonstration of decontamination of fomites, in vitro assays were performed using contaminated glass coverslip and surgical blades as model fomites, following Jensen et al. ${ }^{9}$. Briefly, fresh $P$. aeruginosa culture was diluted to $10^{6} \mathrm{CFU} / \mathrm{ml}$ and $10 \mu \mathrm{l}$ of diluted culture was spread over the fomites and dried for 30 mins at room temperature inside the biosafety cabinet. Thereafter, $100 \mu \mathrm{l}$ of phage lysate was added at MOl: 1 and phage action were allowed for 45 mins, followed by placing the fomites in 500ulfresh TSB, vigorously vortexed for 10 seconds to dislodge the attached bacteria from the fomite surface. A control treatment was performed using sterile phage buffer instead of phage lysate. Cultures were serially diluted and plated on TSA agar and incubated overnight at $37^{\circ} \mathrm{C}$. Colony counting was performed for assessing the decontamination potentials of phage lysates.

\section{Phage lytic activity in vitro:}

Phage kinetics was performed according to Verstappen et al. ${ }^{53}$ with some minor modifications to study in vitro lysis of bacteria through a change in absorbance of optical density. Bacteria in the log phase were diluted to obtain OD 0.05 and phage stock at different MOI: 1, 0.1, 0.01, and 0.001 were aliquoted into transparent 96 -well plates. Change in absorbance at $\mathrm{OD}_{600}$ was recorded at an interval of 10 mins up to 390 min. Incubation temperature was set at $37{ }^{\circ} \mathrm{C}$, which was maintained inside the instrument (Varioskan ${ }^{\text {TM }}$ LUX, Thermo Scientific, USA). Treatment, control, and blank readings were recorded and plotted against time. Reading was taken at 10 min intervals up to 390 mins.

\section{Lyophilization of phage lysate and encapsulation on alginate:}

Lyophilization and phage encapsulation on alginate was performed according to Gonza'lez-Mene'ndez et al. ${ }^{54}$ with slight modifications. Phage lysate (109 $\mathrm{PFU} / \mathrm{ml}$ ) was diluted $1: 1(\mathrm{v} / \mathrm{v})$ in $22 \%$ skim milk and $1.6 \mathrm{M}$ sucrose and the diluted phage was allowed to freeze in $2 \mathrm{ml}$ vials for $24 \mathrm{hrs}$ at $-80^{\circ} \mathrm{C}$. Bacteria cells in log phage were resuspended in skim milk lysate to make a final dilution of(v/v) in $11 \%$ skim milk and $0.8 \mathrm{M}$ sucrose. Samples were lyophilized in a laboratory freeze dryer (Labconco, Kansas City, USA). The lyophilized preparation was reconstituted with 2 ml sterile TM buffer and phage titer was calculated by single layer agar method.

Phage lysate $\left(10^{9} \mathrm{PFU} / \mathrm{ml}\right)$ was diluted (ten times) in $50 \mathrm{mM} \mathrm{TM}$ buffer (pH7.5). The buffer was reconstituted with $2 \%$ (w/v) sodium alginate (Himedia, Mumbai, India). The mixture was stirred for $1 \mathrm{~h}$ continuously at $500 \mathrm{rpm}$ at room temp, and then phage suspension was dropped into $0.1 \mathrm{MCaCl} 2$ solution. Diluted phage was mixed in sodium alginate solutions and the suspension was dropped into calcium chloride solution resulting in the cross-linking of alginate 
with calcium ions thus forming alginate beads. The alginate beads were left in the solution for 30 min at room temperature followed by repeated washing with nuclease-free water and stored at $4^{\circ} \mathrm{C}$.

\section{Statistical analysis}

The unpaired t-test was used for statistical analysis in this study. The level of significance was set at ( $p \leq 0.05)$. GraphPad PRISM version 9.0.1 (221) for windows was used to analyze the data (GraphPad Software, La Jolla, USA).

\section{Conclusion}

Their lytic nature of bacteriophage for specific bacteria makes them a potential candidate for phage therapy. DRLP1 isolated from wastewater is a virulent phage and has lytic potential against $P$. aeruginosa. Phage belongs to the Myoviridae family and active at a wide range of temperature and pH. The ability to decontaminate the fomites and phage action in vitro indicates its efficiency against $P$. aeruginosa makes it an important bioagent.

\section{Declarations}

Conflicts of Interest: The authors declare no conflict of interest.

Acknowledgments: The authors thankfully acknowledge the support of the Defence Research \& Development Organization (DRDO), Ministry of Defence for intramural research funds. We thank Dr. Vanlalhmuaka, and Ms.Shwetnisha, for their kind support with experiments, reagents and instrument facilities. Sincere thanks are also due to Carol DeWeese Scott, Bio Project Curation Staff, and Jon, NCBI BioSample Submissions Staff, Bethesda, Maryland USA for their help with the submission of data to SRA.The authors also extend thanks to Dr. Narendra Kumar, DAVV, Life sciences, Indore for helping in manuscript reviewing.

\section{References}

1. Bassetti, M. et al. Antimicrobial resistance in the next 30 years, humankind, bugs and drugs: a visionary approach. Intensive Care Med. 43 , $1464-1475$ (2017).

2. Hraiech, S., Brégeon, F. \& Rolain, J. M. Bacteriophage-based therapy in cystic fibrosis-associated Pseudomonas aeruginosa infections: rationale and current status. Drug Des Devel Ther. 9, 3653-3663 (2015).

3. Pang, Z., Raudonis, R., Glick, B. R., Lin, T. J. \& Cheng, Z. Antibiotic resistance in Pseudomonas aeruginosa: mechanisms and alternative therapeutic strategies. Adv.37, 177-192 (2019).

4. Sharma, S. et al. Isolation and characterisation of a lytic bacteriophage from wastewater and its application in pathogen reduction. Life Sci. J. 5, 80-86 (2020).

5. Conrad, J. C. et al. Flagella and pili-mediated near-surface single-cell motility mechanisms in aeruginosa. Biophys. J. 100, 1608-1616 (2011).

6. Burrows, L.L. Pseudomonas aeruginosa twitching motility: type IV pili in action. Rev. Microbiol. 66, 493-520 (2012).

7. Gregory, A. C. et al. The gut virome database reveals age-dependent patterns of virome diversity in the human gut. Cell Host Microbe. 28, 724-740 (2020).

8. Schooley, R.T. et al. Development and use of personalized bacteriophage-based therapeutic cocktails to treat a patient with a disseminated resistant Acinetobacter baumanniiAntimicrob. Agents Chemother. 61, e00954-17 (2017).

9. Jensen, K. C. et al. Isolation and host range of bacteriophage with lytic activity against methicillin-resistant Staphylococcus aureus and potential use as a fomites decontaminant. PLoS One,10, e0131714 (2015).

10. Azizian, R. et al. Sewage as a rich source of phage study against Pseudomonas aeruginosaBiologicals. 43, $238-241$ (2015).

11. Pires, D. P., Boas, D. V., Sillankorva, S. \& Azeredo, J. Phage therapy: a step forward in the treatment of Pseudomonas aeruginosaJ. Virol. $89,7449-7456$ (2015).

12. Jamal, M., Hussain, T., Das, C. R. \& Andleeb, S. Characterization of siphoviridae phage Z and studying its efficacy against multidrug-resistant Klebsiella pneumoniae planktonic cells and biofilm. Med. Microbiol.64,454-462 (2015).

13. Gunathilaka, G. U., Tahlan, V., Mafiz, A. I., Polur, M. \& Zhang, Y. Phages in urban wastewater have the potential to disseminate antibiotic resistance. J. Antimicrob. Agents. 50, 678-683 (2017).

14. Mahgoub, S. A., Muhammad, M. I., Abd-Elsalam, S. T., Alkhazindar, M. M. \& Abdel-Shafy, H. I. Isolation and characterization of Pseudomonas aeruginosa and Enterococcus faecalis lytic bacteriophages from wastewater for controlling multidrug resistant bacterial strains. Plant Arch. 20, 450-464 (2020).

15. Pachori, P., Gothalwal, R. \& Gandhi, P. Emergence of antibiotic resistance Pseudomonas aeruginosa in intensive care unit; a critical review. Genes \& diseases. 6, 109-119 (2019).

16. Batra, P., Deo, V., Mathur, P. \& Gupta, A. K. Cotrimoxazole, a wonder drug in the era of multiresistance: Case report and review of literature. J Lab Physicians. 9, 210-213 (2017).

17. Drenkard, E. \& Ausubel, F. M. Pseudomonas biofilm formation and antibiotic resistance are linked to phenotypic variation. Nature, 416, 740-743 (2002).

18. Worlitzsch, D.et al. Effects of reduced mucus oxygen concentration in airway Pseudomonas infections of cystic fibrosis patients. J. Clin. Investig. 109, 317-325 (2002).

19. Motlagh, A. M., Bhattacharjee, A. S. \& Goel, R. Biofilm control with natural and genetically-modified phages. World J. Microb. Biot. 32, 67 (2016).

20. Chegini, Z. et al. A bacteriophage therapy against Pseudomonas aeruginosa biofilms: a review . Clin. Microbiol. Antimicrob.19, 1-17 (2020).

Page $7 / 22$ 
21. Krylov, V.et al. Modular approach to select bacteriophages targeting Pseudomonas aeruginosa for their application to children suffering with cystic fibrosis. microbiol.7, 1631 (2016).

22. Sharma, S. et al. Bacteriophages and its applications: an overview. Folia microbial. 62, 17-55 (2017).

23. Amarillas, L. et al. Isolation and characterization of phills, a novel phage with potential biocontrol agent against multidrug-resistant Escherichia coli. Microbial. 8, 1355 (2017).

24. Yazdi, M., Bouzari, M. \& Ghaemi, E. A. Isolation and characterization of a lytic bacteriophage (vB_PmiS-TH) and its application in combination with ampicillin against planktonic and biofilm forms of Proteus mirabilis isolated from urinary tract infection. Mol. Microbiol. Biotechnol. 28, 37-46 (2018).

25. Rashid, M.H et al. A Yersinia pestis-specific, lytic phage preparation significantly reduces viable pestis on various hard surfaces experimentally contaminated with the bacterium. Bacteriophage.2, 168-177 (2012).

26. Defez, C. et al. Risk factors for multidrug-resistant Pseudomonas aeruginosa nosocomial infection. Hosp. Infect.57, 209-216 (2004).

27. Kay, M. K., Erwin, T. C., McLean, R. J. \& Aron, G. M. Bacteriophage ecology in Escherichia coli and Pseudomonas aeruginosa mixed-biofilm communities. Environ. Microbiol.77, 821-829 (2011).

28. Danis-Wlodarczyk, K. et al. A proposed integrated approach for the preclinical evaluation of phage therapy in Pseudomonas infections. Rep. 6, 1-13 (2016).

29. Fu, W. et al. Bacteriophage cocktail for the prevention of biofilm formation by Pseudomonas aeruginosa on catheters in an in vitro model system. Agents Chemother. 54, 397-404 (2010).

30. Manohar, P. \& Ramesh, N. Improved lyophilization conditions for long-term storage of bacteriophages. Rep. 9, 1-10 (2019).

31. Golec, P. et al. A reliable method for storage of tailed phages. Microbiol. Methods. 84, 486-489 (2011).

32. Liang, L. et al. Development of a lyophilization process for campylobacter bacteriophage storage and transport. Microorganisms. 8, 282 (2020).

33. Moghtader, F., Eğri, S. \& Piskin, E. Phages in modified alginate beads. Artif Cells Nanomed Biotechnol. 45, 357-363 (2017).

34. Sambrook, J. R. \& Russell, D. W. In Molecular Cloning, A Laboratory Manual (eds. Sambrook, J. R. \& Russell, D. W.) 2.1-2.117. (Cold Spring Harbor Laboratory Press, New York, NY, 2001).

35. Gençer, S., Ak, Ö., Benzonana, N., Batırel, A., \& Özer, S. Susceptibility patterns and cross resistances of antibiotics against Pseudomonas aeruginosa in a teaching hospital of Turkey. Clin. Microbiol. Antimicrob.1, 1-4 (2002).

36. Kim, S.G. et al. Isolation and characterisation of pVa-21, a giant bacteriophage with anti-biofilm potential against Vibrio alginolyticus. Sci Rep 9, 6284 (2019).

37. Litt, P. K., \& Jaroni, D. Isolation and physiomorphological characterization of Escherichia coli 0157: H7-infecting bacteriophages recovered from beef cattle operations. J. Microbiol, 2017, 7013236 (2017).

38. Hunt, M. et al. IVA: accurate de novo assembly of RNA virus genomes. J. Bioinform. 31, 2374-2376 (2015).

39. Besemer, J., Lomsadze, A. \& Borodovsky, M. GeneMarks: a self-training method for prediction of gene starts in microbial genomes. Implications for finding sequence motifs in regulatory regions. Nucleic Acids Res. 29, 2607-2618 (2001).

40. Arndt, D. et al. PHASTER: a better, faster version of the PHAST phage search tool. Nucleic Acids Res. 44, W16W21,https://doi.org/10.1093/nar/gkw387(2016).

41. Altschul, S. F. et al. Basic local alignment search tool. J Mol Biol.215, 403-410 (1990).

42. Chan, P.P. \& Lowe, T.M. tRNAscan-SE: searching for tRNA genes in genomic sequences. Methods Mol Biol. 1962 1-14 (2019).

43. Reese, M.G. Application of a time-delay neural network to promoter annotation in the Drosophila melanogasterComput. Chem. 26, 51-56 (2001).

44. Naville, M., Ghuillot-Gaudeffroy, A., Marchais, A., \& Gautheret, D. ARNold: a web tool for the prediction of Rho-independent transcription terminators. RNA Biol.8, 11-13 (2011).

45. McNair, K., Bailey, B. A. \& Edwards, R. A. PHACTS, a computational approach to classifying the lifestyle of phages. Bioinform.28, 614 618 (2012).

46. Alcock, B. P. et al. CARD 2020: antibiotic resistome surveillance with the comprehensive antibiotic resistance database. Nucleic Acids Res.48, D517-D525 (2020).

47. Pruitt, K. D., Tatusova, T. \& Maglott, D. R. NCBI reference sequences (RefSeq): a curated non-redundant sequence database of genomes, transcripts and proteins. Nucleic Acids Res.35, D61-D65 (2007).

48. Hall, Tom A. BioEdit: a user-friendly biological sequence alignment editor and analysis program for Windows 95/98/NT. Nucleic Acids Symp. Ser. 41, 9598 (1999).

49. Katoh, K., Misawa, K., Kuma, K. I. \& Miyata, T. MAFFT: a novel method for rapid multiple sequence alignment based on fast Fourier transform. Nucleic Acids Res. 30, 3059-3066 (2002).

50. Kumar, S., Stecher, G., Li, M., Knyaz, C. \& Tamura, K. MEGA X: molecular evolutionary genetics analysis across computing platforms. Biol. Evol. 35, 15471549 (2018).

51. Moraru, C., Varsani, A. \& Kropinski, A.M. VIRIDIC-A novel tool to calculate the intergenomic similarities of prokaryote-infecting viruses. Viruses, 12, 1268 (2020).

52. Sullivan, M. J., Petty, N. K., \& Beatson, S. A. Easyfig: a genome comparison visualizer. Bioinform. 27, 1009-1010 (2011).

53. Verstappen, K.M. et al. The effectiveness of bacteriophages against methicillin-resistant Staphylococcus aureus ST398 nasal colonization in pigs. PLoS One, 11, e0160242. (2016). 
54. Gonzalez-Menendez, E. et al. Comparative analysis of different preservation techniques for the storage of Staphylococcus phages aimed for the industrial development of phage-based antimicrobial products. PLoS One, 13, e0205728 (2018).

\section{Tables}

Table 1. Predicted ORFs, their positions on the DRL-P1 genome, size, annotations and probable role in phage life cycle. 


\begin{tabular}{|c|c|c|c|c|c|c|c|}
\hline \multirow{2}{*}{$\begin{array}{l}\text { REGIONs/ } \\
\text { ORFs }\end{array}$} & \multicolumn{2}{|l|}{ Span } & \multirow[t]{2}{*}{ Strand } & \multicolumn{2}{|c|}{ Length } & \multirow{2}{*}{$\begin{array}{l}\text { GenBank } \\
\text { annotation }\end{array}$} & \multirow[t]{2}{*}{ Role/ Function in Phage life cycle } \\
\hline & Start & Stop & & ORF & aa & & \\
\hline REGION 1 & 1 & 353 & + & 353 & & Terminal Repeat & Genome replication \& packaging \\
\hline ORF1 & 634 & 3216 & - & 2583 & 860 & Phage internal (Core) protein & Virion Structure \\
\hline ORF2 & 3220 & 3648 & - & 429 & 142 & Phage exonuclease & Genome replication \\
\hline ORF3 & 3658 & 4251 & - & 594 & 197 & Phage tail fiber protein & Host infection \\
\hline ORF4 & 4260 & 4799 & - & 540 & 179 & Hypothetical protein & \\
\hline ORF5 & 4799 & 5302 & - & 504 & 167 & Phage tail fiber protein & Host infection \\
\hline ORF6 & 5312 & 5740 & - & 429 & 142 & Hypothetical protein & \\
\hline ORF7 & 5742 & 6092 & - & 351 & 116 & Phage exonuclease & Replication \\
\hline ORF8 & 6089 & 6412 & - & 324 & 107 & Hypothetical protein & \\
\hline ORF9 & 6412 & 6864 & - & 453 & 150 & Phage tail fiber Protein & Host infection \\
\hline ORF10 & 6922 & 8436 & - & 1515 & 504 & Putative transcriptional regulator & Gene expression \\
\hline ORF11 & 8453 & 9034 & - & 582 & 193 & Hypothetical protein & \\
\hline ORF12 & 9031 & 9582 & - & 552 & 183 & Hypothetical protein & \\
\hline ORF13 & 9590 & 9988 & - & 399 & 132 & Hypothetical protein & \\
\hline ORF14 & 9985 & 10452 & - & 468 & 155 & Hypothetical protein & \\
\hline ORF15 & 10467 & 10904 & - & 438 & 145 & Hypothetical protein & \\
\hline ORF16 & 11006 & 12154 & - & 1149 & 382 & Phage capsid and scaffold Protein & Virion assembly \\
\hline ORF17 & 12164 & 12799 & - & 636 & 211 & Hypothetical protein & \\
\hline ORF18 & 12803 & 14230 & - & 1428 & 475 & Phage capsid and Scaffold protein & Virion assembly \\
\hline ORF19 & 14743 & 14883 & - & 141 & 46 & Hypothetical protein & \\
\hline ORF20 & 14880 & 15086 & - & 207 & 68 & Hypothetical protein & \\
\hline ORF21 & 15106 & 15942 & - & 837 & 278 & Phage minor capsid protein & Virion Structure \& assembly \\
\hline ORF22 & 15942 & 18239 & - & 2298 & 765 & putative minor head protein & Virion Structure \\
\hline ORF23 & 18419 & 18820 & + & 402 & 133 & Hypothetical protein & \\
\hline ORF24 & 18852 & 19175 & + & 324 & 107 & Hypothetical protein & \\
\hline ORF25 & 19172 & 19375 & + & 204 & 67 & Hypothetical protein & \\
\hline ORF26 & 19381 & 19692 & + & 312 & 103 & Hypothetical protein & \\
\hline ORF27 & 19776 & 20288 & + & 513 & 170 & Hypothetical protein & \\
\hline ORF28 & 20392 & 21324 & + & 933 & 310 & Hypothetical protein & \\
\hline ORF29 & 21321 & 21416 & + & 96 & 31 & Hypothetical protein & \\
\hline ORF30 & 21426 & 22019 & + & 594 & 197 & Hypothetical protein & \\
\hline ORF31 & 22036 & 22473 & + & 438 & 145 & Hypothetical protein & \\
\hline ORF32 & 22559 & 23338 & + & 780 & 259 & Hypothetical protein & \\
\hline ORF33 & 23341 & 23775 & + & 435 & 144 & Hypothetical protein & \\
\hline ORF34 & 23820 & 24170 & + & 351 & 116 & Hypothetical protein & \\
\hline ORF35 & 24170 & 24388 & + & 219 & 72 & Hypothetical protein & \\
\hline ORF36 & 24385 & 24768 & + & 384 & 127 & Hypothetical protein & \\
\hline ORF37 & 24805 & 26187 & - & 1383 & 460 & Phage terminase, large subunit & $\begin{array}{l}\text { DNA translocation and packaging } \\
\text { termination }\end{array}$ \\
\hline ORF38 & 26387 & 26575 & + & 189 & 62 & Hypothetical protein & \\
\hline ORF39 & 26695 & 26841 & + & 147 & 48 & Hypothetical protein & \\
\hline ORF40 & 26852 & 27154 & + & 303 & 100 & Hypothetical protein & \\
\hline
\end{tabular}




\begin{tabular}{|c|c|c|c|c|c|c|c|}
\hline ORF41 & 27201 & 28118 & + & 918 & 305 & Phage tail length tape-measure protein & Genome injection \\
\hline ORF42 & 28121 & 28309 & + & 189 & 62 & Hypothetical protein & \\
\hline ORF43 & 28389 & 28574 & + & 186 & 61 & Hypothetical protein & \\
\hline ORF44 & 28699 & 28899 & + & 201 & 66 & Hypothetical protein & \\
\hline ORF45 & 28896 & 29111 & + & 216 & 71 & Hypothetical protein & \\
\hline ORF46 & 29108 & 29299 & + & 192 & 63 & Hypothetical protein & \\
\hline ORF47 & 29296 & 29508 & + & 213 & 70 & Hypothetical protein & \\
\hline ORF48 & 29536 & 30183 & + & 648 & 215 & Hypothetical protein & \\
\hline ORF49 & 30180 & 30506 & + & 327 & 108 & Putative single-stranded DNA binding protein & Genome replication \\
\hline ORF50 & 30572 & 30796 & + & 225 & 74 & Hypothetical protein & \\
\hline ORF51 & 30850 & 31077 & + & 228 & 75 & Phage dihydrofolate reductase & DNA synthesis \\
\hline ORF52 & 31087 & 31308 & + & 222 & 73 & Hypothetical protein & \\
\hline ORF53 & 31356 & 31673 & + & 318 & 105 & $\begin{array}{l}\text { Phage single-stranded-DNA-specific } \\
\text { exonuclease }\end{array}$ & Genome replication \\
\hline ORF54 & 31683 & 32309 & + & 627 & 208 & Phage putative head protein & Virion Structure \\
\hline ORF55 & 32502 & 33116 & + & 615 & 204 & Hypothetical protein & \\
\hline ORF56 & 33279 & 33857 & - & 579 & 192 & Hypothetical protein & \\
\hline ORF57 & 34388 & 34618 & - & 231 & 76 & Hypothetical protein & \\
\hline ORF58 & 34817 & 36547 & - & 1731 & 576 & Phage-associated DNA primase & Genome replication \\
\hline ORF59 & 36695 & 36880 & - & 186 & 61 & Hypothetical protein & \\
\hline ORF60 & 36886 & 37962 & - & 1077 & 358 & Hypothetical protein & \\
\hline ORF61 & 37959 & 38408 & - & 450 & 149 & Hypothetical protein & \\
\hline ORF62 & 38408 & 39250 & - & 843 & 280 & Hypothetical protein & \\
\hline ORF63 & 39381 & 40166 & - & 786 & 261 & Hypothetical protein & \\
\hline ORF64 & 40334 & 40756 & + & 423 & 140 & Hypothetical protein & \\
\hline ORF65 & 40743 & 41930 & + & 1188 & 395 & Capsid decoration protein & Virion Structure \\
\hline ORF66 & 42092 & 42982 & + & 891 & 296 & Hypothetical protein & \\
\hline ORF67 & 43087 & 44088 & + & 1002 & 333 & Hypothetical protein & \\
\hline ORF68 & 44178 & 44408 & + & 231 & 76 & Hypothetical protein & \\
\hline ORF69 & 44408 & 44626 & + & 219 & 72 & Hypothetical protein & \\
\hline ORF70 & 44610 & 44828 & + & 219 & 72 & Phage tail assembly protein & Virion Structure \\
\hline ORF71 & 44828 & 45094 & + & 267 & 88 & Hypothetical protein & \\
\hline ORF72 & 45106 & 45312 & + & 207 & 68 & Phage minor tail protein & Virion Structure \\
\hline ORF73 & 45312 & 46229 & + & 918 & 305 & Thymidylate synthase & DNA synthesis \\
\hline ORF74 & 46231 & 46422 & + & 192 & 63 & Phage tail assembly protein & Virion Structure \\
\hline ORF75 & 46425 & 47465 & + & 1041 & 346 & 5'Polynucleotide kinase-3'phosphatase & DNA damage repair \\
\hline ORF76 & 47541 & 48095 & + & 555 & 184 & Hypothetical protein & \\
\hline ORF77 & 48095 & 51202 & + & 3108 & 1035 & Phage DNA polymerase III alpha subunit & Genome replication \\
\hline ORF78 & 51195 & 51605 & + & 411 & 136 & Phage Recombination protein & General recombination \\
\hline ORF79 & 51602 & 53161 & + & 1560 & 519 & Phage DNA Helicase & Genome replication \\
\hline ORF80 & 53256 & 53876 & + & 621 & 206 & Phage tail fiber protein & Virion Structure / Host infection \\
\hline ORF81 & 53965 & 54861 & + & 897 & 298 & Hypothetical protein & \\
\hline ORF82 & 54917 & 55522 & + & 606 & 201 & Hypothetical protein & \\
\hline ORF83 & 55519 & 56073 & + & 555 & 184 & Phage DNA Binding protein & Genome replication \\
\hline ORF84 & 56127 & 57038 & + & 912 & 303 & $\begin{array}{l}\text { Phage DNA Ligase } \\
\text { Page } 11 / 22\end{array}$ & Genome replication \\
\hline
\end{tabular}




\begin{tabular}{|llllllll|}
\hline ORF85 & 57318 & 57569 & + & 252 & 83 & Hypothetical protein & Host cell Lysis \\
\hline ORF86 & 57594 & 58256 & - & 663 & 220 & Phage endolysin & Virion Structure \\
\hline ORF87 & 58256 & 58684 & - & 429 & 142 & Phage tail fiber component & Virion Structure \\
\hline ORF88 & 58687 & 61581 & - & 2895 & 964 & Phage tail fiber protein & Virion Structure \\
\hline ORF89 & 61586 & 63100 & - & 1515 & 504 & Hypothetical protein & Virion Structure \\
\hline ORF90 & 63097 & 64350 & - & 1254 & 417 & Phage tail assembly protein & Virion Structure \\
\hline ORF91 & 64407 & 65072 & - & 666 & 221 & Baseplate protein & Genome replication \& packaging \\
\hline ORF92 & 65128 & 65661 & - & 534 & 177 & Hypothetical protein & \\
\hline ORF93 & 65661 & 66128 & - & 468 & 155 & Phage minor tail protein & Terminal Repeat \\
\hline REGION2 & 65891 & 66243 & + & 353 & & &
\end{tabular}

Table.2 Details of recombination events detected in the DRL-P1 complete genome.

\begin{tabular}{|c|c|c|c|c|c|c|c|c|c|c|}
\hline \multirow[t]{2}{*}{ Events } & \multicolumn{2}{|c|}{$\begin{array}{l}\text { Breakpoint } \\
\text { Positions } \\
(99 \% \mathrm{Cl})\end{array}$} & \multicolumn{2}{|c|}{ Parental sequences most similar to RefSeq } & \multicolumn{6}{|c|}{ Detection Method } \\
\hline & Begin & End & Minor parent & Major parent & RDP & GENECONV & BOOTSCAN & MAXCHI & CHIMAERA & SI: \\
\hline 1 & $\begin{array}{l}* 1- \\
2508\end{array}$ & $\begin{array}{l}27450- \\
27676\end{array}$ & NC_050150_antinowhere & NC_011810_PB1 & NS & 7.63E-05 & 1.39E-05 & $\begin{array}{l}3.44 \mathrm{E}- \\
03\end{array}$ & NS & $2 .:$ \\
\hline 2 & $\begin{array}{l}12952- \\
13552\end{array}$ & $\begin{array}{l}15791- \\
16070\end{array}$ & NC_048662_R12 & NC_41902_PA5 & $\begin{array}{l}3.87 \mathrm{E}- \\
11\end{array}$ & NS & $9.28 \mathrm{E}-12$ & $\begin{array}{l}4.06 \mathrm{E}- \\
14\end{array}$ & $5.68 \mathrm{E}-17$ & 1.c \\
\hline 3 & $\begin{array}{l}30300- \\
30982\end{array}$ & $\begin{array}{l}\text { 31037- } \\
31179\end{array}$ & NC_028745_DL60 & NC_050150_antinowhere & NS & 6.07E-06 & NS & $\begin{array}{l}2.13 \mathrm{E}- \\
03\end{array}$ & 2.33E-04 & 9.6 \\
\hline 4 & $\begin{array}{l}34741- \\
34864\end{array}$ & $\begin{array}{l}35766- \\
36483\end{array}$ & NC_048744_EPa61 & NC_007810_F8 & $\begin{array}{l}2.17 \mathrm{E}- \\
02\end{array}$ & NS & 4.30E-03 & $\begin{array}{l}1.02 \mathrm{E}- \\
09\end{array}$ & 7.24E-07 & Ns \\
\hline 5 & $\begin{array}{l}34742- \\
36409\end{array}$ & $\begin{array}{l}36756- \\
49890\end{array}$ & NC_048663_R26 & NC-007810_F8 & NS & 4.52E-04 & 2.89E-06 & $\begin{array}{l}3.05 \mathrm{E}- \\
03\end{array}$ & NS & Ns \\
\hline 6 & $\begin{array}{l}\text { 37757- } \\
39593\end{array}$ & $\begin{array}{l}40875- \\
41707\end{array}$ & NC_011810_PB1 & NC_048744_EPa61 & $\begin{array}{l}2.78 \mathrm{E}- \\
03\end{array}$ & 4.94E-05 & 2.02E-02 & $\begin{array}{l}7.31 \mathrm{E}- \\
07\end{array}$ & $1.89 \mathrm{E}+05$ & 5.2 \\
\hline 7 & $\begin{array}{l}40875- \\
41089\end{array}$ & $\begin{array}{l}41394- \\
41482\end{array}$ & NC_048745_SCUTS1 & NC_050145_PaGU11 & NS & 4.24E-07 & $6.04 \mathrm{E}-18$ & $\begin{array}{l}5.99 \mathrm{E}- \\
05\end{array}$ & $2.91 \mathrm{E}-04$ & 2.4 \\
\hline 8 & $\begin{array}{l}42697- \\
42783\end{array}$ & $\begin{array}{l}49313- \\
50275\end{array}$ & NC_007810_F8 & NC_050143_datas & $\begin{array}{l}1.81 \mathrm{E}- \\
34\end{array}$ & $5.00 \mathrm{E}-59$ & $3.02 \mathrm{E}-52$ & $\begin{array}{l}1.76 \mathrm{E}- \\
22\end{array}$ & 3.73E-14 & $4 . \varsigma$ \\
\hline 9 & $\begin{array}{l}54844- \\
55619\end{array}$ & $\begin{array}{l}58859- \\
59079\end{array}$ & NC_048744_EPa61 & NC_011810_PB1 & $\begin{array}{l}4.78 \mathrm{E}- \\
66\end{array}$ & 3.75E-88 & 1.38E-92 & $\begin{array}{l}1.20 \mathrm{E}- \\
37\end{array}$ & $1.13 \mathrm{E}-38$ & 6.1 \\
\hline 10 & $\begin{array}{l}40432- \\
59079\end{array}$ & $\begin{array}{l}59115- \\
59433\end{array}$ & NC_041870_DP1 & NC_050150_antinowhere & NS & 3.31E-12 & 1.87E-12 & $\begin{array}{l}2.63 \mathrm{E}- \\
04\end{array}$ & 1.35E-04 & Ns \\
\hline 11 & $\begin{array}{l}59386- \\
59605\end{array}$ & $\begin{array}{l}59938- \\
60186\end{array}$ & NC_007810_F8 & NC_019935_KPP12 & $\begin{array}{l}5.51 \mathrm{E}- \\
70\end{array}$ & $8.01 \mathrm{E}-73$ & $1.85 \mathrm{E}-72$ & $\begin{array}{l}1.82 \mathrm{E}- \\
13\end{array}$ & $6.12 \mathrm{E}-13$ & 5.4 \\
\hline 12 & $\begin{array}{l}59838- \\
61747\end{array}$ & $\begin{array}{l}62466- \\
62776\end{array}$ & NC_028745_DL60 & NC_007810_F8 & NS & NS & 2.87E-05 & $\begin{array}{l}4.85 \mathrm{E}- \\
09\end{array}$ & $1.85 \mathrm{E}-05$ & Ns \\
\hline
\end{tabular}

NS, Not Significant

\section{Figures}


a
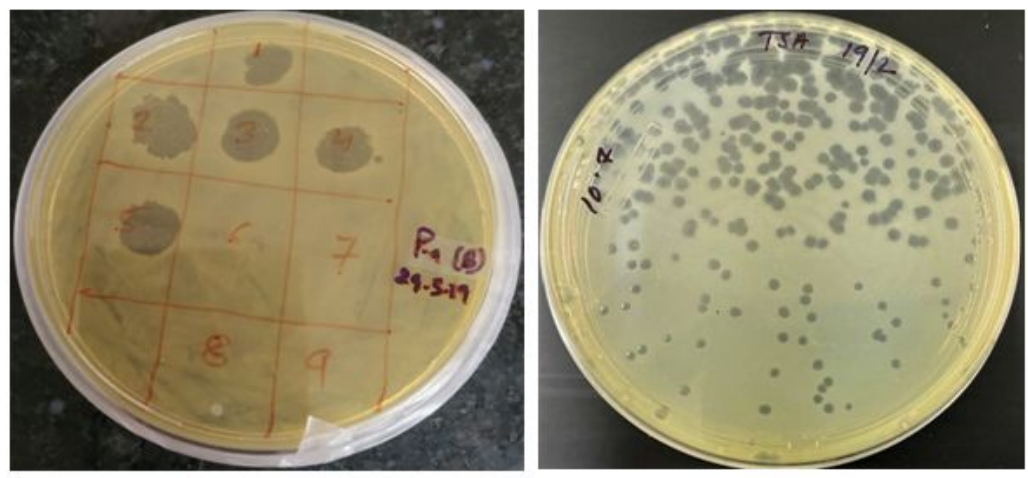

b

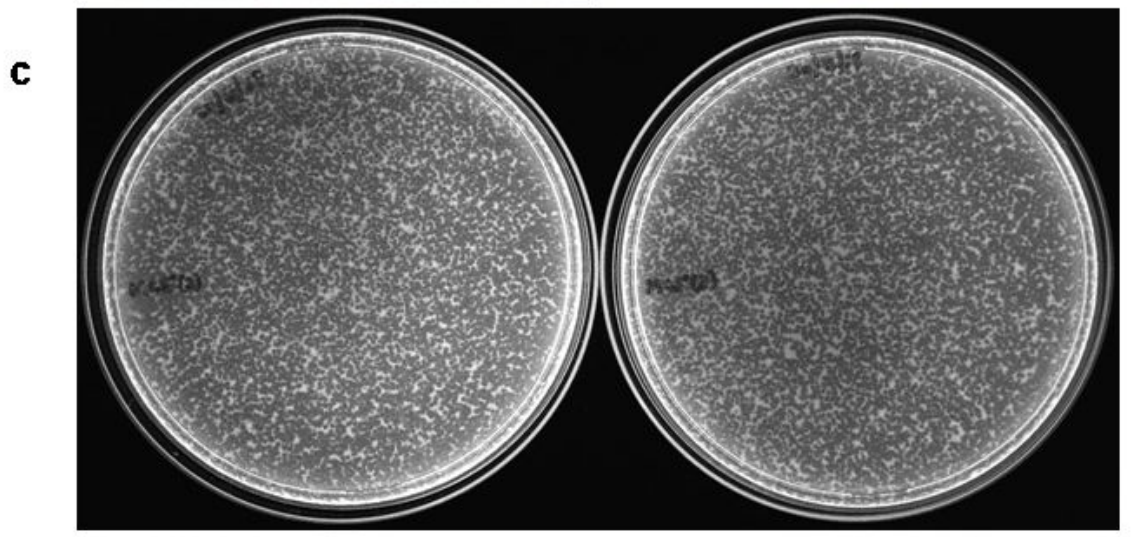

Figure 1

(a) Spot Test of phage over the lawn of P. aeruginosa (b) Enriched plaques (c) Webbed plates for phage lysate preparation.
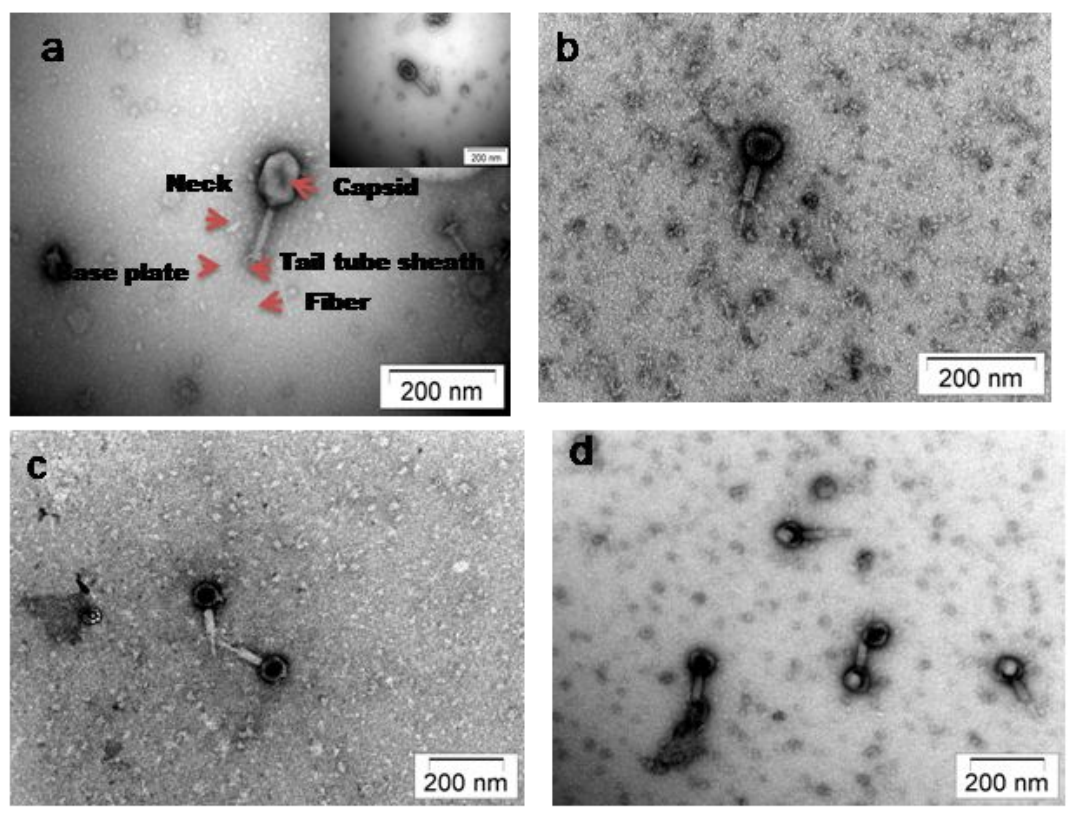

Figure 2

(a) (b) (c) (d) Showing transmission electron micrographs (TEM) of DRLP-1. 


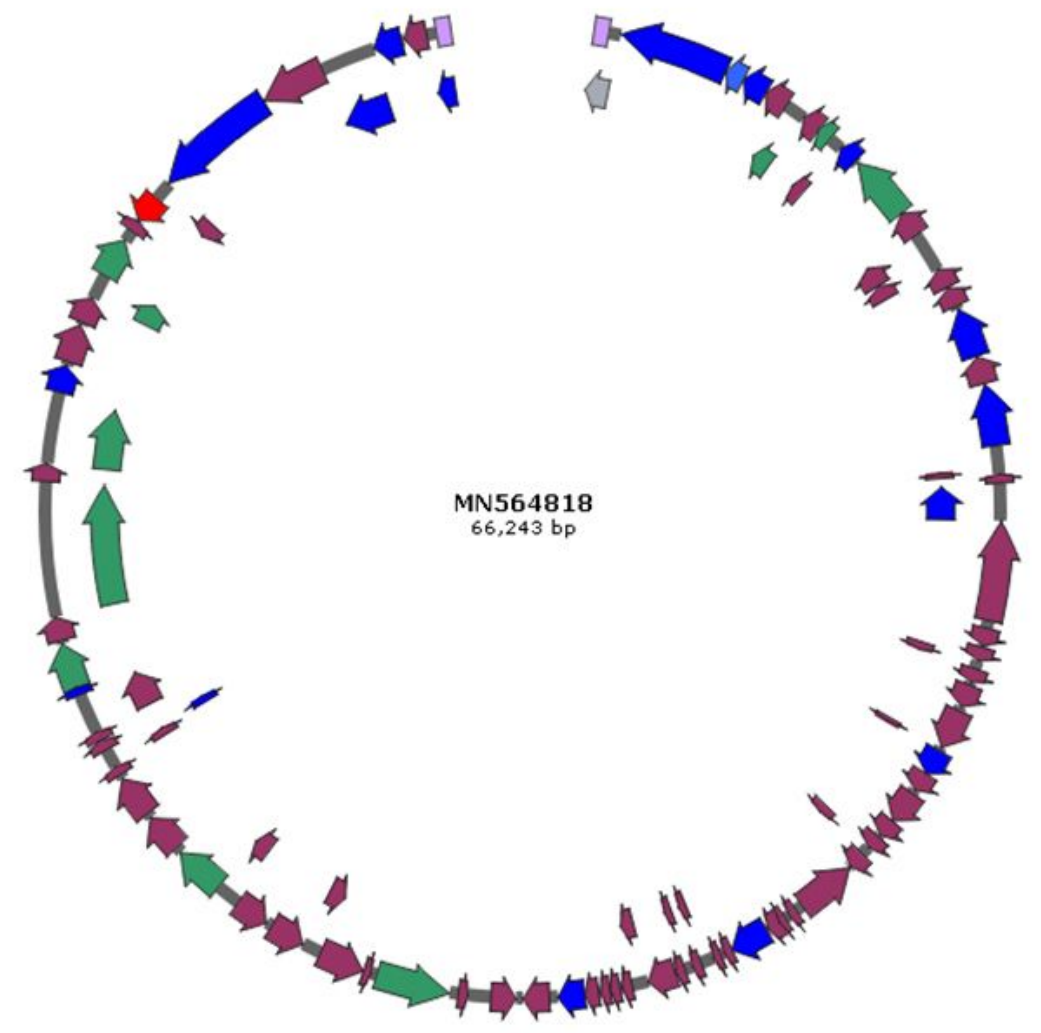

Figure 3

Genome Map of the phage DRL-P1 linear dsDNA. Colurs: Blue, Structural genes; Green, Functional genes; Red, Endolysin; Maroon, Hypothetical genes; Lavender, Terminal repeats. Details of the genetic regions are presented in the annotation Table 1. 


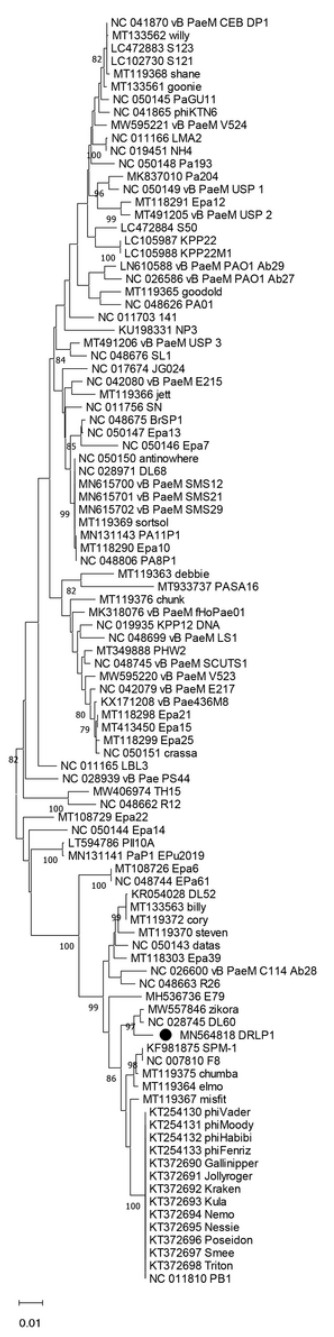

Figure 4

Neighbor-Joining phylogenetic tree based on the large terminase gene. 


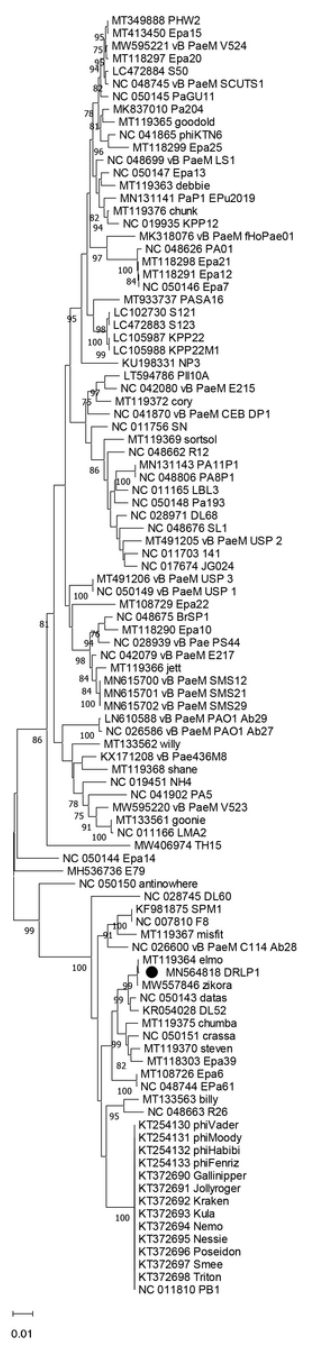

Figure 5

Neighbor-Joining phylogenetic tree based on the DNA polymerase III gene 


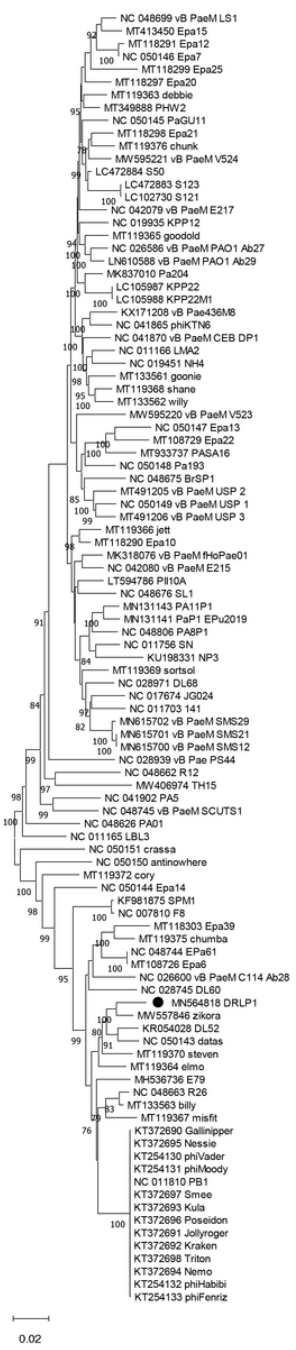

Figure 6

Neighbor-Joining phylogenetic tree based on complete genome sequences. 


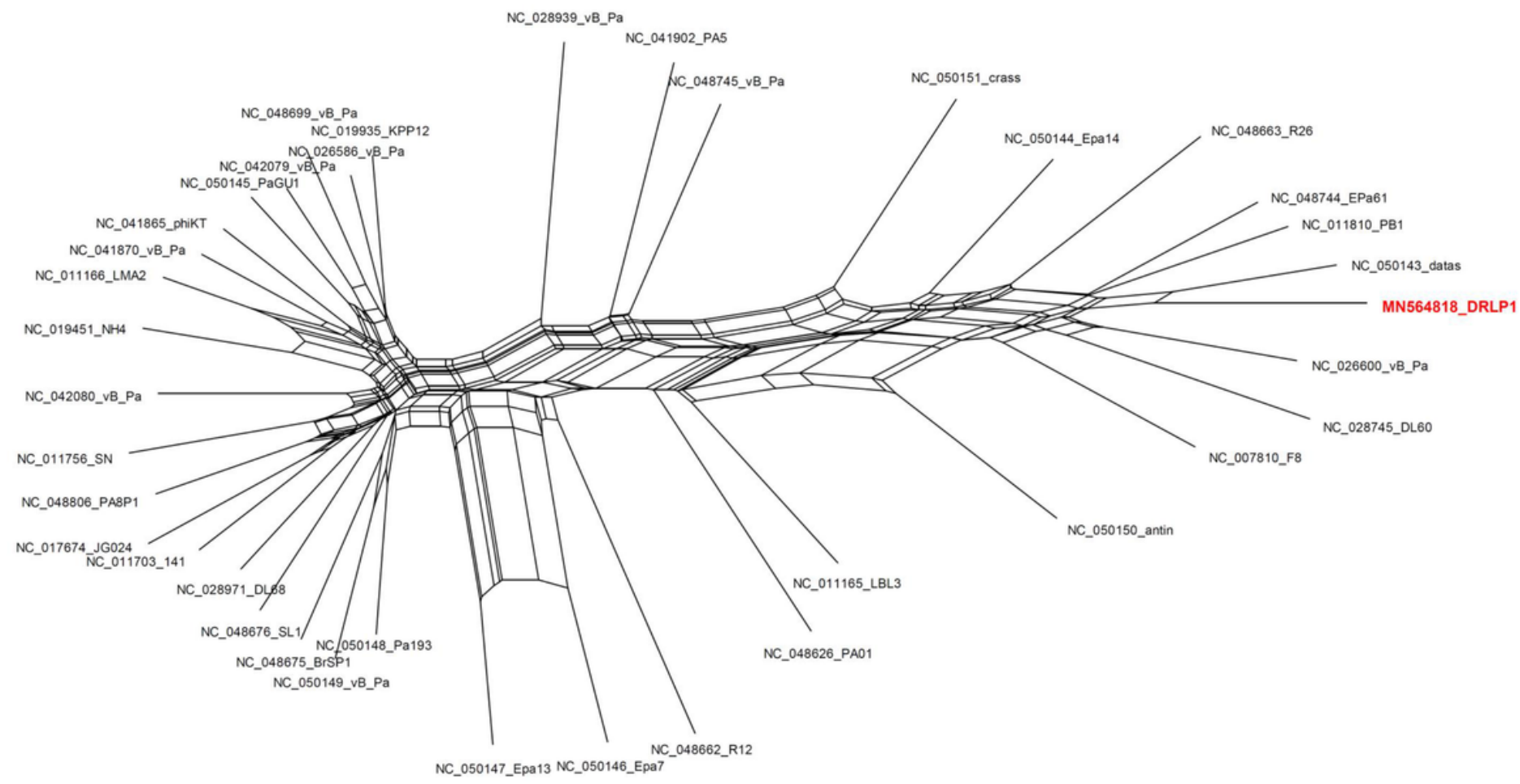

Figure 7

NN reconstructed with RefSeq and DRL-P1 complete genome sequence.

MN564818_DRAP1

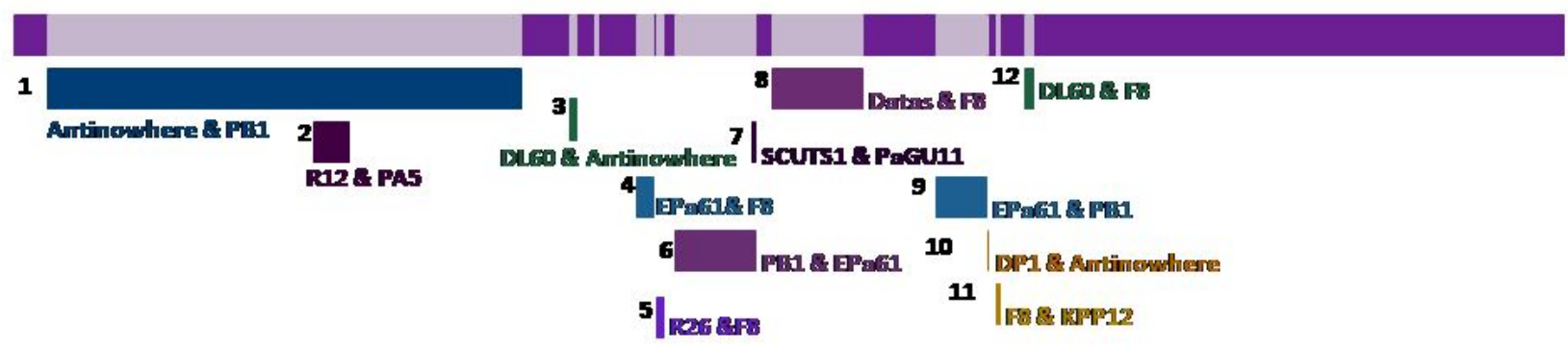

Figure 8

Recombination map showing 12 recombination events detected by the RDP4 program in the DRL-P1 genome. Details of these recombination events are provided in the Table 2. Minor and Major parent involved in each of the recombination events is indicated by the most similar RefSeq isolate name. 
A)

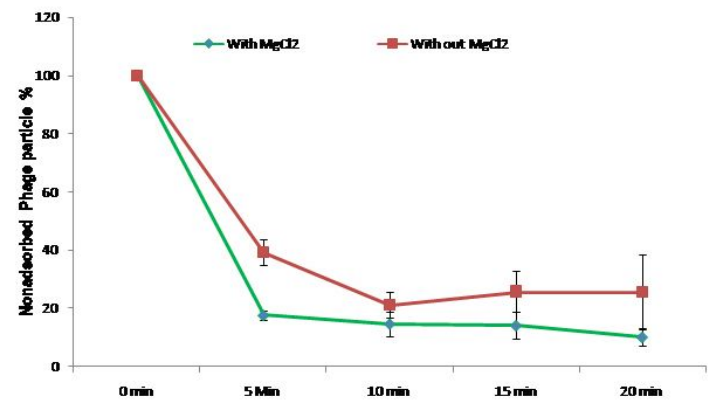

B)

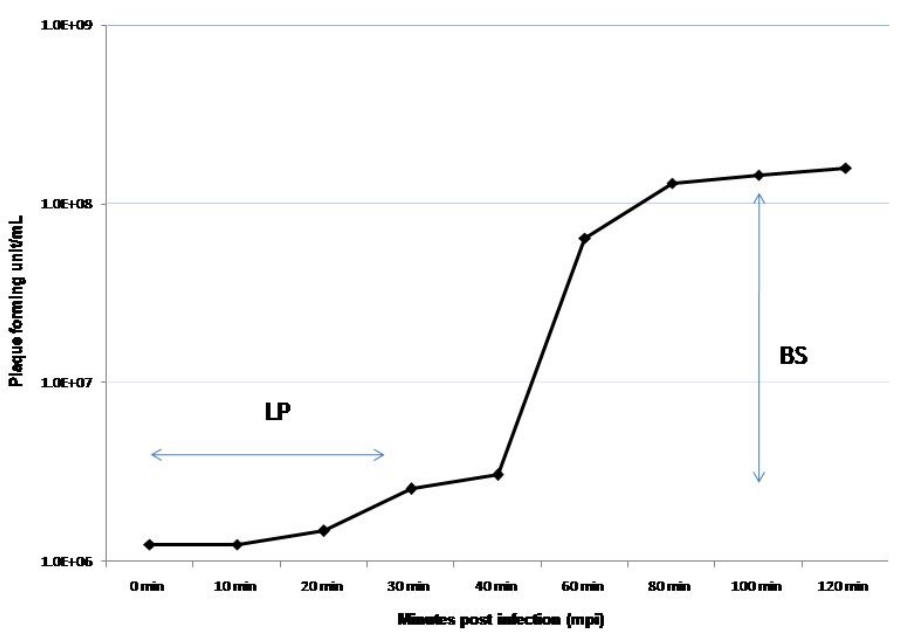

Figure 9

(a) Effect of magnesium ion on adsorption rate of P. aeruginosa bacteriophage (DRLP-1). (b) Single step growth curve of P. aeruginosa bacteriophage (DRLP1). 


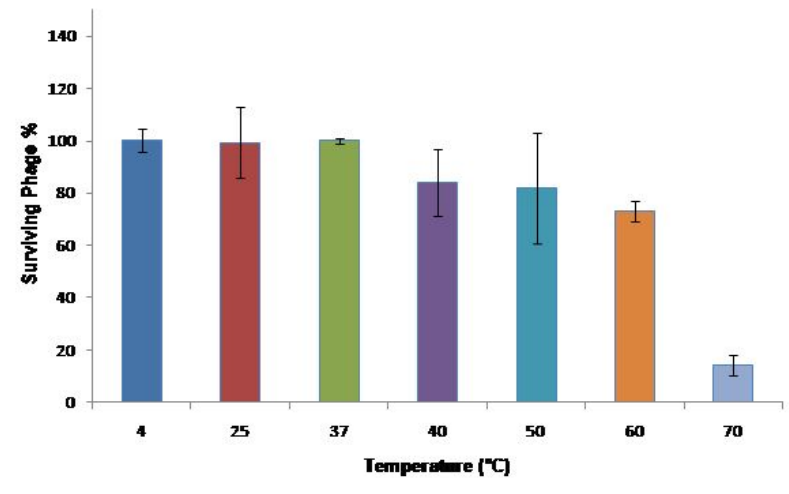

A)

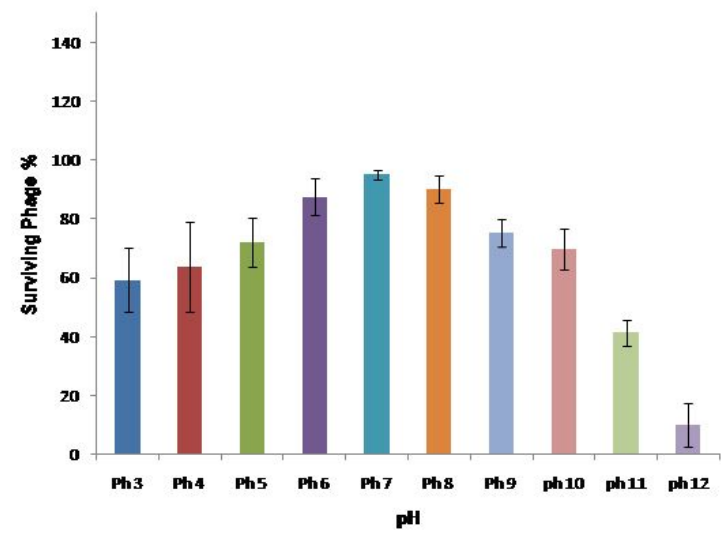

B)

\section{Figure 10}

(a) Stability of DRLP-1 at different temperature $\left(4^{\circ} \mathrm{C}, 25^{\circ} \mathrm{C}, 37^{\circ} \mathrm{C}, 40^{\circ} \mathrm{C}, 50^{\circ} \mathrm{C}, 60^{\circ} \mathrm{C}\right.$ and $\left.70^{\circ} \mathrm{C}\right)$. Data were displayed as mean $\pm \mathrm{SD}$ of three independent experiments. (b) Stability of DRLP-1 at different $\mathrm{pH}[2,3,4,5,6,7,8,9]$. Data were displayed as mean \pm SD of three independent experiments. 
A)

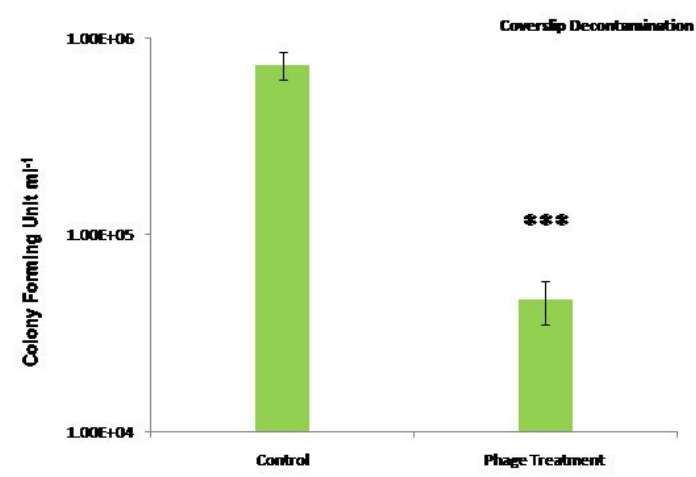

B)

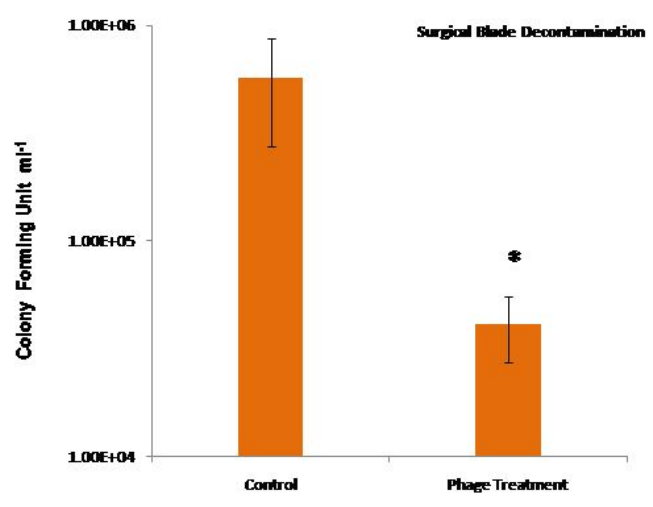

\section{Figure 11}

(a) Decontamination of artificially contaminated glass cover slip with DRLP-1 application and Bar graph representing reduction in P. aeruginosa CFU after phage treatment. Data was analysed through unpaired, two tailed student t-test when comparing phage treated vs. control samples ( $p \leq .05)$. (b)

Decontamination of artificially contaminated surgical blade by DRLP-1 application. Bar graph representing reduction in P. aeruginosa CFU after phage treatment. Data were displayed as mean \pm SD of three independent experiments $(p \leq .05)$. 


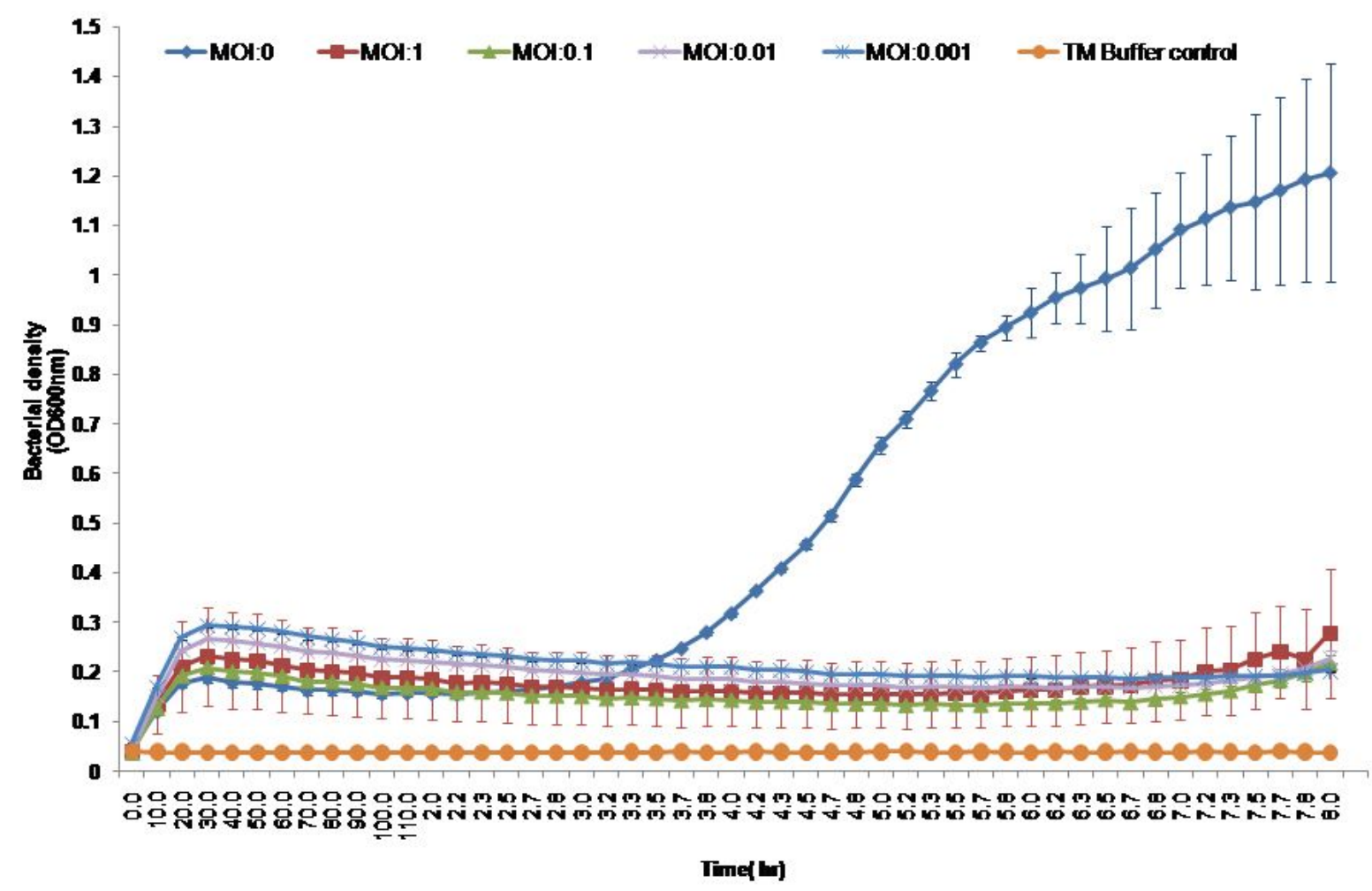

Figure 12

In vitro lytic activity of DRLP-1 at different MOI.

\section{Supplementary Files}

This is a list of supplementary files associated with this preprint. Click to download.

- SupplementaryDataofmanuscript.docx 